\title{
Tax Adjustment and Analysis of Enterprise Investment Management Business
}

\author{
Jiabing $\mathrm{Xu}$ \\ North China Electric Power University in Beijing \\ 18810795207@163.com
}

Keywords: Investment management; Tax adjustment; Income tax; Enterprise

\begin{abstract}
With the initial establishment of China's socialist market economic system, as one of the main body of the market economy, the enterprise's business model of self-financing and independent operation has been established and improved. In order to enhance the competitiveness of enterprises to diversify management operations, and seek long-term business stability and healthy development, one of the most important measures is the timely and appropriate investment activities. The income and investment assets obtained from investment management have also become the most important assets of many enterprises.
\end{abstract}

\section{Introduction}

In order to better control and standardize the accounting of enterprise investment management business, the Ministry of Finance promulgated the "Accounting Standard for Enterprises Investment Management" in 1998. Later, a series of income tax policies related to investment management tax treatment and investment management were successively promulgated. Due to the different purposes and methods of the income tax law and the accounting system, there are differences in the timing and specific classification of the income of the investment management, resulting in different accounting costs and tax costs in the investment management business. The purpose of this paper is to analyze the tax adjustment of investment management by analyzing the similarities and differences between income tax and accounting treatment in investment management.

\section{The Comparison of the Accounting Treatment and Tax Treatment in the Investment Management Business}

Investment management refers to the investment assets obtained by the exchange of the assets held by investors with the enterprises in which they are invested because they want to get dividends to achieve capital appreciation or to improve trade relations and so on.

In this article, investment management business mainly focuses on two kinds: one is the management of debt investment, and the other is the equity investment management. Simply speaking, the investor agrees with the investee party and they have signed the contract or agreement. The investment that both sides agree to pay interest at the time of maturity is creditor's right investment. Apart from debt investments, other investments are called equity investments. To distinguish an investment management business, it is necessary to combine the terms and conditions to see the purpose of the cooperation between the two, the relationship between the two, the risks and benefits of the investment, the capital structure of the two enterprises, etc. The essence of the formal considerations of the principle of form can be finalized.

Income Tax Treatment Divides the Investment Income into Dividend Interest and the Income of Investment Transfer. In the financial accounting system of the enterprise, the total investment management income of the enterprise is generally embodied in the "investment income" account. However, according to the requirements of the income tax law, the income of the enterprise's investment management should be divided into dividend interest and the income of investment transfer.

In the aspect of the management of debt investment, if the enterprise holds the national debt, its interest income will be exempt from the enterprise income tax, and the proceeds from the disposal 
of the government bonds will be included in the taxable income.

For the management of enterprise equity investment, its dividend income is not the same as the tax treatment of the profit of the capital gains. The total amount of the transfer income in the disposal of equity investment by an enterprise should be incorporated into the taxable income of the enterprise. The dividend income is obtained by the investment enterprise from the post tax profit of the invested enterprise, which belongs to the after-tax income of the collected income tax. In order to avoid double taxation, the current policy stipulates that only for the dividend income that is returned from the low value tax area not because of the preferential tax deduction and tax deduction, the enterprise income tax of the differential tax rate part should be made up.

However, if the investment is inadvertently incurred, the investee has suffered a loss during the course of its operation, the investment losses confirmed under the management of the "equity method" of the invested enterprise and the losses incurred during the process of the transfer and disposal of the investors, and the methods of tax administration are also different. The losses incurred by the investee, if managed according to the regulations, must be made when the enterprise is profitable in the future and the deducted deductions in the realized income cannot be used to offset the taxable income directly.

Under the equity law management accounting system, if the investee is in a loss and net profit is negative, investment management should make additional tax adjustment for the investment losses automatically recognized at the end of the accounting period. Special attention is paid to the liquidation of enterprise assets transfer and investment management of investment disposal losses is deducted before tax, What calls for special attention is that the loss of investment management caused by the transfer and disposal investment of the assets in liquidation of an enterprise can be deducted before tax. The loss of equity investment deducted from each tax year shall not exceed the income of the equity investment and the income of the transfer of investment management, which is realized in the year. If it exceeds, it will be deducted after a later tax year and can be postponed indefinitely.

The Regulation of the Time and Amount of the Investment Income are Different from the Tax Law and the Accounting System in the Investment Management Business. The first one is that the provisions on the source of the "dividend income" project are different. The accounting system stipulates that "dividend income" refers to the surplus reserve and accumulated retained earnings generated from the investments received by the investee company. However, the tax law does not classify it as the profit after the invested party accepts the investment. The amount allotted by the investor from after-tax profits should be included in the dividend income of the invested unit. As for the distribution of bonus shared by the enterprise, that is, when the surplus reserve is converted into capital, the tax administration measures are also deemed to be distributed according to the nominal value of the shares.

The second one is that the provisions of short-term equity investment management are different. Financial accounting provides for the recognition of gains or losses on investment transfers. The tax administration required by tax law should make a strict distinction between the income of dividends and the proceeds or losses of the investment transfer. Dividend income is recognized when the investee makes profit distribution.

The third one is that under the administration of equity method, the time of recognition of long-term equity investment is different from the tax law. Accounting requirements shall be recognized at the end of each fiscal year according to the share of the net profits or net losses incurred by the investee during the current year, and the balance of book value of the investment management business shall be adjusted accordingly. However, the tax law stipulates that the investee should confirm the investment income after the actual distribution and at the same time, it should not recognize the loss of the investee as the investment loss of the enterprise.

Tax Administration Does Not Allow Short-Term Investments to Make Provisions for Impairment and Long-Term Investment Impairment Provisions. The accounting system stipulates that enterprises can prepare for fall prices and long-term investment according to the change of market prices. However, according to the tax law, this is not allowed, and can not only be 
based on the change of the market price to identify the loss.

Tax Law Does Not Allow Confirming the Equity Investment Difference. According to the accounting standards, "the long-term equity investment under the equity method, the difference between the investment cost of the investor and the share of the owner of the investee should be treated as the balance of the equity investment." If the cost of investment exceeds the share of owner's equity, borrowing is goodwill; otherwise, it is a loan difference.

\section{The Adjustment of the Cost of Accounting and the Cost of Tax in the Investment Management Business}

The tax and accounting are different to the management of investment management business, so the tax cost of investment management is not the same as the accounting cost.

The total cost that enterprises actually pay for investment management is the taxable cost of the investment required by the tax law, which includes taxes, fees and other related expenses. Regardless of the size of the amount, the cost of investment should be counted. And if the expenses related to the long-term debt investment occur, if the amount is small, it will be deducted directly at the time of purchase. If the amount is large, the investment cost will be accounted for separately.

When an enterprise initially invested in a business, the interest of the bonds that included the declared dividends that had not yet been paid and the interest on the bonds that had been paid in installments were taxed according to the income of investment management. Accordingly, the tax cost of investment management is reduced, and the income tax treatment is the same as the accounting treatment.

In order to avoid double taxation, enterprises should make immediate and effective adjustments to the taxable costs of investment as long as the economic transaction process that causes the tax cost of investment to change during the process of holding the investment.

Next, let's compare the tax adjustments and accounting costs of the investment management business:

\section{Short-Term Equity Investment Management.}

Adjusted short-term equity investment accounting cost $=$ initial investment cost + additional investment - dividends actually received distribution - investment costs recovered.

Adjusted short-term equity investment tax cost $=$ initial investment cost + additional investment - investment costs recovered.

\section{Short-Term Debt Investment Management.}

Adjusted short-term debt investment accounting cost $=$ initial investment cost + additional investment - dividends actually received distribution - the cost of investment recovered

Adjusted short-term debt investment tax cost $=$ initial investment cost + additional investment - the investment has been reduced. 


\section{Long-Term Equity Investment Management.}

1. Long-term equity investment under the equity method:

Adjusted long-term equity investment cost of accounting $=$ initial investment cost (including the initial investment amount - declared but not yet received the dividend) + except for the net profit of the invested enterprise should be shared by the invested unit to realize the profit or confirmed the interest Increase in project + realized investment transfer income + additional investment and improved expenditure - dividend declared to be paid loss incurred or loss of equity due to investee - investment recovered - lost investment transfer realized, etc.

2. In accounting, whether it is the cost law or the rights and interests law:

Adjusted long-term equity investment taxable cost $=$ cost of investment (initial investment amount - declared but not paid at the time of investment) + additional investment later + investment transfer realized in the investment process - recovered investment - already confirmed investment transfer losses.

\section{Long-Term Debt Investment.}

The tax cost of the adjusted debt interest on the investment $=$ cost of the investment + the realized income from the investment - the amortization of the related expenses - the investment transfer losses recognized in the investment.

The tax cost of debt investment of debt service with the repayment of principal and interest as of maturity $=$ investment cost at the beginning of the period + interest income that has been recognized but not actually collected + income from the investment that has been realized - transfer loss of the investment confirmed - actual Interest income due.

\section{Related Income Tax Treatment in the Management of Equity Investment}

The investment income that a company receives from the investee's profit after equity investment is the income from equity investment management. In order to avoid double taxation, dividend income is a corporate income tax that has been levied. According to the current policies and regulations, the enterprise income tax rate applicable to the investee is less than the tax rate applicable to the investee, and the tax balance due to the impact of the tax rate difference should be levied. However, the investee carries out the regular tax relief policy, so the actual tax burden is less than the investor, so the overdue tax doesn't need to be paid.

Income from dividend investment management is the arbitrary payment obtained by the enterprise from the accumulated net profit of the investee. If the amount of payment of the invested unit obtained by the enterprise exceeds the above amount of investment recovery, the cost of the investment tax should be reduced. When calculating or adjusting the management tax cost for an enterprise that exceeds the investment itself, it includes the income over the tax cost of investment when the investment is transferred. This is the nature of the capital gains from investment management, and vice versa, it is taken as an adjustment to the investment management loss.

As for the recognition time of equity investment, the current standard stipulates that as long as the actual operation of profit distribution is used in the financial accounting system of the investee, the investor confirms the investment income regardless of the actual payment.

The dividend income accrued by the enterprise shall be consolidated into the invested enterprise at the time of profit distribution with the investee (including the conversion of the surplus reserve 
into share capital and its distribution of shares) irrespective of the actual receipt of dividends taxable income, which in accordance with the law to calculate and pay corporate income tax. If there is no more than the investment according to the applicable tax rates credit limit, dividend income is from enterprise income tax deduction should be truly exempt; while the exemption limit is greater than a specified offset part in the enterprise after tax year carried forward. The deduction and exemption of the income tax of the enterprise income tax are calculated according to the different investment management items respectively.

If the investee makes a loss, the loss can only be made up by the enterprise before the adjustment and calculation of the enterprise income tax, and the investor unit cannot make up for the tax when calculating the enterprise income tax.

\section{Conclusions}

This paper briefly introduces the similarities and differences between accounting and tax treatment in investment management business, and the adjustment of tax cost and adjustment in investment management business, and further analyzes the related income tax treatment in corporation equity investment. Through tax adjustment and analysis of enterprise investment business, we can better analyze the financial operation of enterprises and better manage enterprises, so as to help enterprises achieve long-term stable and healthy development.

\section{References}

[1] P.Jin: Analysis of the Difference between Tax Law and Accounting Standard in Enterprise Investment Management Business, China Taxation Publishing House, 2008:3(21).(In Chinese)

[2] L.Liu: The Difference between the Accounting Treatment and the Tax Treatment for the Investment Management Business, Finance and Accounting for International Commerce, 2010:4(23).(In Chinese)

[3] Y.Jiang: Discussion on the Coordination of Tax Accounting and Tax Planning, Public Finance Research, 2011.(In Chinese) 